\title{
A FÉ ESTÁ ON-LINE: SOBRE INTERNET E TELEFONES CELULARES NAS PRÁTICAS RELIGIOSAS DE UM GRUPO POPULAR
}

\author{
ONLINE FAITH: NOTES ON INTERNET AND CELLPHONE USE IN THE \\ RELIGIOUS PRACTICES OF A LOW-INCOME GROUP
}

\author{
LA FE ESTÁ ONLINE: ACERCA DE LA INTERNET Y LOS TELÉFONOS \\ MÓVILES EN LAS PRÁCTICAS RELIGIOSAS DE UM GRUPO POPULAR
}

\author{
Sandra Rubia da Silva \\ Docente do Departamento de Ciências da Comunicação \\ da Universidade Federal de Santa Maria \\ sandraxrubia@gmail.com
}

\begin{abstract}
Resumo
Este artigo apresenta os resultados de uma investigação etnográfica sobre formas de apropriação da Internet e de telefones celulares nas práticas religiosas dos habitantes (em especial, os evangélicos) de um bairro popular em Curitiba - PR. O referencial teórico remete a Horst e Miller (2006), Prandi (2006); Castells et al. (2007) e Bell (2006) que, entre outros, analisam o atravessamento da vivência da religiosidade pelas tecnologias de comunicação e informação. Práticas como o envio de versículos bíblicos por celular, a evangelização on-line e o aconselhamento via Internet e telefone, por exemplo, dão conta da crescente - e ainda pouco estudada - apropriação da tecnologia por grupos populares, que aqui nos propomos analisar sob a ótica do sagrado.
\end{abstract}

Palavras-chave: Tecnologias de comunicação e informação. Religiosidade. Grupos populares.

\begin{abstract}
This paper presents the results of an ethnographic study on the forms of appropriation of the Internet and cellphones in the religious practices of the dwellers (especially the Pentecostals) of a low-income group in the city of Curitiba, South Brazil. The theoretical framework refers to the works of Horst and Miller (2006); Prandi (2006); Castells et al. (2007) and Bell (2006) who, among others, have analysed the role of information and communication technologies in the experience of religion. Practices such as the sending of Bible versicles via SMS, online evangelization, and counseling via Internet and telephones, for instance, give account of the growing - although still scarcely studied - appropriation of technology by low-income groups, which is to be studied here through the viewpoint of the sacred.
\end{abstract}

Keywords: Information and communication technologies. Religiosity. Low-income groups. 


\section{Resumen}

Este artículo presenta los resultados de una investigación etnográfica acerca de las formas de apropiación de la Internet y de los teléfonos móviles en las prácticas religiosas de los habitantes (especialmente de los evangélicos) de un barrio popular de la ciudad de Curitiba, Brasil. El encuadre teórico es basado en los trabajos de Horst y Miller (2006); Prandi (2006); Castells et al. (2007) y Bell (2006), los cuales, dentre otros, analisan el atravesamiento de la experiencia de la religiosidad por las tecnologias de comunicación y información. Prácticas como el envio de versículos bíblicos por SMS, la evangelización online, y el aconsejamiento por la Internet y el leléfono, por ejemplo, dan cuenta de la cresciente - pero aún poco estudada - apropiación de la tecnología por los grupos populares, que aqui intentamos analisar por la óptica del sagrado.

Palavras-clave: Tecnologías de comunicación y información. Religiosidad. Grupos populares.

Esta obra está licenciada sob uma Licença Creative Commons

\section{INTRODUÇÃO}

As formas de apropriação e consumo das tecnologias de comunicação e informação (TICs) têm sido prioritariamente pensadas, no campo de conhecimento que se convenciona chamar de antropologia do ciberespaço ou cibercultura, a partir de enquadres que enfatizam a construção de identidade ou a expressão de si no universo on-line, as similaridades e descontinuidades entre os âmbitos do "real" e do "virtual" (HINE, 2004) ou mesmo, mais recentemente, o papel das TICs para o desenvolvimento e a inclusão digital nos países em desenvolvimento (CASTELLS et al, 2007). Os estudos em torno de uma antropologia do ciberespaço e no ciberespaço, no campo das ciências sociais, e os estudos em cibercultura (termo mais corrente no campo da Comunicação) têm apontado, assim, para o caráter pervasivo e ubíquo das tecnologias de comunicação e informação (em especial, a Internet), as quais exercem, na contemporaneidade, grande influência sobre os mais variados domínios da vida social. As estatísticas mais recentes (março de 2011) indicam que, para uma população que se aproxima da casa dos sete bilhões de habitantes, já somos mais de dois bilhões de internautas ${ }^{1}$. O acesso aos telefones celulares supera ainda mais o de computadores conectados à Internet - já são mais de seis bilhões e duzentos milhões os celulares em

\footnotetext{
${ }^{1}$ De acordo com o site www.worldinternetstats.com.
} 
operação no mundo e, no Brasil, há mais telefones celulares - duzentos milhões - do que habitantes (TELECO, 2012) muito embora deva ser levado em consideração o fato de muitos possuírem mais de um aparelho ou chip de celular.

A investigação aqui apresentada, entretanto, procura situar-se em um domínio relativamente pouco estudado, construindo seu objeto de estudo na intersecção entre as práticas de religiosidade e a apropriação tecnológica. Este estudo deriva de um trabalho de pesquisa anterior, de cunho etnográfico (SILVA, 2011) que se debruçou sobre os impactos da apropriação de telefones celulares ${ }^{2}$ entre mulheres em situação de pobreza ou extrema pobreza, beneficiárias do Programa Bolsa Família, residentes na cidade de Curitiba - PR. Aquela análise, apoiando-se em autores que advogam tanto a centralidade das tecnologias móveis na modernidade, bem como seu papel para o desenvolvimento, explorou as diversas práticas, expectativas e representações dessas mulheres no que tange às tecnologias de comunicação e informação. A análise dos dados de campo revelou quatro temáticas predominantes: primeiro, a preocupação com o custo das tarifas de telefonia móvel; segundo, a relevância do telefone celular para o cuidado com os filhos, a manutenção dos laços familiares e o bem-estar geral da família como um todo; terceiro, o papel dos telefones celulares na geração de renda, no mundo do trabalho e no auxílio em momentos de doença; e, por fim, a conscientização da importância do acesso à Internet para a educação e a empregabilidade, especialmente dos filhos.

Assim, em outro lugar (SILVA, 2011) argumento que o telefone celular possui papel relevante na manutenção dos laços sociais, especialmente entre as mães e seus filhos, mas não somente. Encontrei redes relacionadas tanto com o parentesco quanto com a religião. Do primeiro tipo, temos o exemplo de mães que são imigrantes do Nordeste do Brasil e vieram morar na Vila Sandra. A posse de um telefone celular é instrumental no contato com os parentes que ficaram na terra natal. Entretanto, há casos pungentes, com o de Valdelita, que estudou apenas dois anos na escola. Há seis anos Valdelita não consegue contato com seus pais, que moram na Região Amazônica. De outro lado, há o caso de Odete, que foi separada do irmão no nascimento. Uma tia localizou o irmão, após trinta anos, em uma cidade vizinha.

\footnotetext{
${ }^{2}$ Em que pese o extraordinário fato de que mais de 150 milhões de pessoas que, em muitos casos, não tinham telefone algum passaram a ser usuárias de telefonia através dos celulares no espaço de pouco mais de dez anos apesar de os custos de telefonia móvel no Brasil estarem reconhecidamente entre os mais altos do mundo (BARRANTES; GALPERIN, 2008), muito pouco se têm estudado na academia sobre o caso brasileiro.
} 
Odete recebeu uma ligação surpresa desse irmão em seu celular. Combinaram um encontro e, atualmente, Odete recebe quase diariamente mensagens carinhosas de texto de seu irmão, que Odete guarda zelosamente em seu celular (mas não pode receber fotos, pois seu celular é simples e não têm câmera fotográfica). O caso de Odete é representativo daquilo que Vincent e Fortunati (2009) têm denominado electronic emotion, a fim de pensar na dinâmica das emoções tal como mediadas pelas tecnologias de comunicação e informação.

Embora a outra investigação (SILVA, 2011) tivesse um enfoque mais voltado para o papel das TICs para o desenvolvimento econômico e a inclusão social, chamou-nos a atenção o papel dos telefones celulares na vivência de religiosidade, tema que surgiu transversalmente ao longo de nosso trabalho de campo naquela ocasião ${ }^{3}$. Tal temática, aliás, também foi objeto de estudo em minha tese de doutorado, na qual investiguei o caráter sociocultural do consumo de telefones celulares em um bairro de camadas populares, bem como a influência das tecnologias móveis nas dinâmicas das relações de gênero e geracionais, os processos de apropriação tecnológica e a expressão de si associada ao uso de telefones celulares (SILVA, 2010). Entre as redes de relações sociais mantidas em conexão através dos telefones celulares, a mais significativa possuía caráter religioso, sendo constituída por membros de uma igreja pentecostal - Assembleia de Deus - que tinham como prática enviar mensagens de texto (SMS) com conteúdo bíblico como forma de apoio emocional. Em especial no caso de líderes religiosas (como no caso de Edineia, uma de minhas interlocutoras, que era esposa de um pastor) o uso do celular era constante: Edineia possuía três celulares e duas baterias, pois nunca podia ficar indisponível para as fiéis. Edineia colocava seu número à disposição para membros e não membros da Assembleia de Deus, que podiam buscar apoio emocional a qualquer hora do dia ou da noite em momentos de crise - como, por exemplo, mulheres

\footnotetext{
${ }^{3}$ Durante as oito semanas de trabalho de campo na Vila Sandra (entre o final de agosto e o início de outubro de 2010) eu e minha assistente de pesquisa logramos entrevistar quarenta e uma mulheres, número esse que superou a proposta inicial de entrevistar entre vinte e trinta informantes. Todas estavam em situação de vulnerabilidade social e apenas uma não estava inscrita no Programa Bolsa-Família. De acordo com o Ministério do Desenvolvimento Social, o "Bolsa Família é um programa de transferência direta de renda com condicionalidades, que beneficia famílias em situação de pobreza e de extrema pobreza. O Programa integra o Fome Zero que tem como objetivo assegurar o direito humano à alimentação adequada, promovendo a segurança alimentar e nutricional e contribuindo para a conquista da cidadania pela população mais vulnerável à fome. O Bolsa Família atende mais de 12 milhões de famílias em todo o território nacional. A depender da renda familiar por pessoa (limitada a R\$ 140), do número e da idade dos filhos (até o limite de dezessete anos), o valor do benefício recebido pela família pode variar entre R\$ 22 a R\$ 200. Diversos estudos apontam para a contribuição do Programa na redução das desigualdades sociais e da pobreza”. Disponível em: <http://www.mds.gov.br/bolsafamilia> Acesso em: 20 jan. 2011.
} 
sofrendo situação de violência doméstica ou com familiares envolvidos com consumo de drogas.

Assim, ao observar na Vila Sandra a formação de redes de apoio entre mulheres e também entre religiosos e seus seguidores através do uso de telefones celulares, bem como o papel do telefone celular na vivência de religiosidade, gostaria de apresentar aqui um primeiro estágio de um estudo comparativo, avançando a hipótese de que as dinâmicas observadas na etnografia feita em Florianópolis para minha tese de doutorado também ocorrem em outras localizações etnográficas. Na Vila Sandra, assim como no bairro popular que estudei em Florianópolis, encontrei relevante vivência de religiosidade associada ao telefone celular, especialmente por parte de membros das religiões pentecostais (mais de sessenta por cento das informantes entrevistadas em 2010 declararam pertencer à alguma religião pentecostal). Como mostram Mariano (1999) e Mariz (1994), o crescimento das religiões pentecostais no Brasil tem superado em muito a de outros países. Na Vila Sandra, não é diferente: há praticamente um templo religioso em cada esquina, por menor que seja. As denominações são inúmeras, das mais conhecidas (Assembleia de Deus, Igreja do Evangelho Quadrangular, Adventista do Sétimo Dia, Igreja Batista, Congregação Cristão do Brasil) àquelas que aparentemente só existem na Vila Sandra, como a Visão Missionária e a Casa Favorita.

Os dados empíricos aqui apresentados tem origem em comentários a respeito de tecnologia e religiosidade feitos pelas nossas entrevistadas na pesquisa de 2010, bem como de uma entrevista com um dos líderes religiosos da comunidade. Além disso, apresentamos o mapeamento do uso de sites de redes sociais na Internet por três das igrejas pentecostais estabelecidas na Vila Sandra: Assembleia de Deus, Igreja do Evangelho Quadrangular e Igreja Evangélica Pentecostal Casa Favorita. Nosso argumento é o de que o consumo de Internet e telefones celulares reveste-se de um caráter religioso, no qual a tecnologia torna-se parte do “projeto de Deus para o mundo”, como observaram Miller e Slater (2000) em seu estudo etnográfico da Internet em Trinidad; igualmente, queremos argumentar, concordando com o argumento de Oosterbaan (2011) em seu estudo sobre a Igreja Universal do Reino de Deus, que as práticas de religiosidade que são suportadas pelo consumo de Internet e telefones celulares fazem parte de uma cultura da convergência, na categorização proposta por Jenkins (2009).

Na primeira parte do trabalho, apresento um panorama sobre a influência das tecnologias de comunicação e informação - especialmente dos telefones celulares - nas 
práticas e na vivência da religiosidade. A partir dos casos apresentados, discuto o consumo religioso de Internet e telefones celulares baseada no pressuposto de que tais usos devem ser analisados como “práticas tecno-espirituais” (BELL, 2006) nas quais a experiência da religiosidade ganha novos âmbitos em termos de sensorialidade e mediação. Discuto também a noção de tensão entre religião e tecnologia, especialmente a partir das práticas religiosas de seguidores dos cultos de matriz africana no Brasil, a qual contrasta com a aceitação maior que as tecnologias de comunicação e informação recebem no meio evangélico. Na segunda parte do trabalho, analiso os dados etnográficos relativos às práticas religiosas relatadas pelas informantes, e apresento como várias de tais práticas - especialmente a do testemunho, na qual os fiéis ressaltam o cumprimento da "promessa de Deus" em suas vidas - são traduzidos para o ciberespaço, em termos de uma remediação (BOLTER E GRUSIN, 1999) da prática religiosa.

\section{AS PRÁTICAS TECNO-ESPIRITUAIS: PENSANDO O CONSUMO DE TECNOLOGIAS DE COMUNICAÇÃO E INFORMAÇÃO NA VIVÊNCIA DE RELIGIOSIDADE}

Entre as diversas dimensões da vida sociocultural afetadas pelo advento da Internet e dos telefones celulares, gostaria de argumentar que a da vivência da religiosidade e do sobrenatural está entre as mais fascinantes. O tema tem suscitado a atenção de muitos estudiosos que trabalham na interface dos campos da Antropologia e da Comunicação, originando trabalhos que versam sobre temáticas tão distintas quanto a comunicação com os mortos pelo telefone celular, que viceja no bojo de toda uma cultura popular nas Filipinas associada com visões de fantasmas (BARENDREGT E PERTIERRA, 2008) quanto com o uso de hinos evangélicos como toques de celular (ringtones) entre grupos de pentecostais na Jamaica que, na análise de Horst e Miller (2006) funcionam como forma de reforço e expressão da identidade religiosa, desta forma propiciando o fortalecimento da coesão social.

Bell (2006) e Katz (2006) argumentam acertadamente que diversas formas de arranjos midiáticos envolvendo telefones celulares, computadores, acesso à Internet, e mesmo jogos eletrônicos, têm funcionado como apoio à toda uma série de necessidades de cunho religioso e espiritual. Assim, não é surpresa constatar que, na medida em que a Internet e os telefones celulares tornaram-se tão intimamente imbricados no tecido da vida cotidiana na maior parte do mundo, tanto dão suporte quanto criam novas práticas associadas à vivência da 
religiosidade. É justamente à toda essa dinâmica de apropriação de um tecno-objeto de caráter globalizado (AGAR, 2003) nas experiências religiosas que Bell (2006) irá denominar “práticas tecno-espirituais”. Na argumentação da autora, as interconexões entre consumo tecnológico e práticas de caráter religioso e espiritual merecem atenção, na medida em que três quartos da humanidade identificam-se com alguma religião. Assim sendo, a identificação religiosa torna-se uma "parte importante do que significa ser humano" (BELL, 2006, p. 144). Entretanto, Bell ressalta as tensões que parecem existir no imaginário pertinente à interação entre humanos e computadores (ou aparatos tecnológicos como telefones celulares) e o domínio do sagrado. Em suas palavras:

Então como podemos falar sobre os nascentes usos tecno-espirituais das
TICs? Como podemos celebrar tais práticas em nossos contos do ciberespaço
e utopias tecnológicas? Falar sobre religião é lidar com um terreno contestado
que é altamente pessoal e emocional e cada vez mais politizado. Em muito da
tradição científica ocidental na qual muitos de nós [antropólogos] fomos
treinados, a religião é tida como oposição; nesse enquadramento, a tecnologia
e a computação corporificam um pensamento racional e lógico, e não o
religioso, o espiritual, talvez até o místico. Tal posicionamento é, claro,
profundamente irônico, e estranhamente a-histórico. Pois, no Ocidente, há um
longo e complexo relacionamento entre a tecnologia e a religião; instituições
religiosas foram rápidas em adotar os avanços que tornaram possível que
operassem com maior eficácia e eficiência. (Bell, 2006, p. 145, tradução
minha) ${ }^{4}$.

Assim, a questão que se coloca é: seria possível ter experiências espirituais on-line? Se sim, de que forma tais experiências acontecem? Como relacioná-las com formas ditas mais “tradicionais” (leiam-se, também, presenciais) de vivência da prática religiosa? Bell (2006) advoga que sim, fornecendo vários exemplos que vão desde a influência das "novas mídias” nas práticas religiosas do islamismo até a indicação de que sessenta e quatro por cento dos norte-americanos que usam a Internet já a experimentaram para práticas tecno-espirituais, tais

\footnotetext{
${ }^{4}$ No original: "So how might we talk about the nascent techno-spiritual usages of ICTs? How might we celebrate these practices in our tales of cyberspace and technological utopias? To talk about religion is to traverse contested ground that is highly personal and emotional and increasingly politicized. In much of the western scientific tradition in which many of us were trained, religion is held as an opposition; in this framework, technology and computing embody rational thinking and logic, not religion, the spiritual, perhaps the mystical. This positioning is of course, deeply ironic, and oddly a-historical. After all, in the West, there is a long and complex relationship between technology and religion; religious institutions have been quick to adopt the advances that allowed them to operate with greater efficiencies and/or efficacies” (Bell, 2006, p. 145).
} 
como enviar e receber cartões com conteúdo religioso, ou buscar informações sobre eventos e assuntos de caráter religioso. Interessante notar que o número de americanos utilizando a Rede para práticas religiosas supera o número de americanos que usam a Internet para jogos de azar, ou mesmo para realizar transações bancárias (BELL, 2006). Já Campbell (2006) em seu estudo sobre a apropriação do telefone celular por grupos de judeus ultra-ortodoxos em Israel, chama a atenção para o fato de que as dinâmicas de tensão e aceitação são mediadas pela construção social que dela fazem seus usuários. Ao apenas aceitarem usar celulares kosher (inclusive com certificação especial das operadoras, que se comprometem a bloquear funções consideradas impróprias, tais como o envio de mensagens de texto e o acesso à Internet) os judeus estudados por Campbell demonstram sua força como consumidores ao estabelecerem como norma para seu grupo usos não originalmente previstos. Assim, o celular kosher "representa uma negociação única entre uma comunidade religiosa distinta e uma operadora de telefonia celular, o que resulta na construção da tecnologia como forma cultural que atende a desejos específicos e ideais religiosos” (CAMPBELL, 2006, p. 148).

Em minha própria pesquisa sobre a apropriação de telefones celulares entre camadas populares, pude constatar as dinâmicas de tensão e consumo associadas ao papel dos telefones celulares na vivência de religiosidade (SILVA, 2009). Ao pesquisar entre integrantes da Assembleia de Deus e também entre seguidores de cultos afro-brasileiros (especialmente da umbanda) pude constatar uma maior aceitação da incorporação dos telefones celulares nas práticas religiosas dos evangélicos do que dos umbandistas. Para os últimos, a questão do segredo é fundamental - um jovem ogã (participante do ritual umbandista) teceu muitas reclamações contra aqueles que filmavam as giras (sessões de umbanda) às escondidas e disponibilizavam no You Tube, resultando assim que todos, incluindo os não-iniciados, teriam acesso. Entretanto, embora no caso dos evangélicos de uma forma geral fosse permitido, por exemplo, levar o celular para o culto, as tensões também ocorriam. Estas relacionavam-se em especial à interdição de conteúdos considerados impróprios (“do mundo”) tais como canções e vídeos seculares, que não poderiam fazer parte de um “celular evangélico” (SILVA, 2009).

Nesse sentido, Prandi (2005) indica uma fragilização das religiões afro-brasileiras frente à massiva expansão das religiões neopentecostais: "[nos últimos] vinte anos, mudou muito a forma como a religião é oferecida pelos mais bem-sucedidos grupos religiosos” (PRANDI, 2005, p. 235). Para Prandi, a própria constituição das religiões afro-brasileiras em 
grupos pequenos, de caráter familiar e doméstico, contribui para sua fraqueza nesse cenário em que, a partir da década de 80 , a religião típica se torna uma religião de massa. Prandi sublinha não somente o caráter grandioso dos imensos templos das religiões evangélicas, mas também as constantes transmissões dos cultos pelo rádio e pela TV, tornando o acesso ao discurso religioso imediato e fácil - o que também já foi demonstrado por Mariano (1999). Em contraste, com as religiões neopentecostais, Prandi acredita que a massificação é uma mudança à qual a umbanda e o candomblé não são afeitos, já que

[...] a vida religiosa de um afro-brasileiro se pauta principalmente pelo desempenho de papéis sacerdotais dentro de um grupo de características eminentemente familiares. Não é à toa que o grupo de culto é chamado de família-de-santo. Mais que isso: as cerimônias secretas das obrigações e sacrifícios não são abertas sequer a todos os membros de um terreiro: há sempre uma seleção baseada nos níveis iniciáticos, não sendo concebível a exposição de todos, muito menos sua divulgação por meio televisivo. (PRANDI, 2005, p. 236).

Embora concordando com Prandi no que tange ao argumento da massificação, gostaria de argumentar que, se a televisão não faz parte das formas de apresentação da religião afrobrasileira aos seus fiéis, as tecnologias de comunicação e informação (Internet, celulares) estão presentes no cotidiano de vivência de religiosidade de seus adeptos. Prandi (2005) não cita a Internet em sua análise, mas no registro do estudo das religiões afro-brasileiras começam a surgir, na virada para o século XXI, pesquisas que indicam sua inserção nas religiões afro-brasileiras. Tramonte (2001) que conduziu extensa pesquisa em Florianópolis sobre a constituição dos grupos afro-brasileiros locais, em suas trajetórias, práticas e concepções, encerra seu livro com uma breve, porém significativa, análise da presença de páginas na Internet para três dos terreiros que pesquisou. Segundo a autora, além de informações específicas do grupo (como entidades-guia e endereço) há nos sites conteúdos que visam proporcionar um aprofundamento dos conhecimentos religiosos:

Sem violar preceitos, o terreiro desvenda suas atividades práticas e orientações espirituais a quem deseja conhecê-las, possibilitando um acesso democrático e contribuindo para a desmistificação da religião. Pode-se afirmar que esta é uma estratégia de expansão de sua influência, na qual a Internet emerge como uma poderosa aliada da modernidade na inserção e veiculação das tradições do povo-de-santo’” (TRAMONTE, 2001, p. 469).

ANIMUS R. Interamericana de Comunicação Midiática, http://www.ufsm.br/revistas E-ISSN 2175-4977, v. 11, n. 21, Jan-Jun(2012) 
Em outro lugar (TRAMONTE, 1999) a autora elenca a existência, já no final do século vinte, de inúmeros sites de terreiros de umbanda e candomblé por todo o Brasil (são citados especificamente grupos da Bahia, Rio Grande do Sul, São Paulo e Santa Catarina) além de diversos links para bibliotecas e livrarias especializadas, programas de rádio (como o de Pai Celso de Oxalá em São Paulo) e organizações não-governamentais. Embora reconhecendo a convergência entre modernidade e tradição presente nessas dinâmicas, e reconhecendo seu caráter positivo como estratégia para aumentar seu campo de influência, a autora indica que a adoção da Internet nas religiões afro-brasileiras não se dá sem conflitos. Nesse sentido, registra em sua análise a preocupação das lideranças religiosas com o controle das informações divulgadas nas mídias eletrônicas; estas, porém segundo a autora (TRAMONTE, 2001) tendem cada vez mais a acolher a complexidade dos fenômenos tecnológicos contemporâneos. Assim, “a informatização dos terreiros das religiões afro-brasileiras é apenas um facilitador para todos aqueles que desejam contatos ou aprofundamento no conhecimento das práticas espirituais” (TRAMONTE, 2001, p. 471).

No campo da Comunicação, Freitas (2008) já observou no final do século passado o fenômeno que transporta as religiões afro-brasileiras do mundo da oralidade para o ambiente do hipertexto, o qual denominou “ciberinformatização do candomblé”, tendo como base pesquisa desenvolvida entre 1998 e 2001 para sua tese de doutorado. Diferentemente de Tramonte (2001) que analisou uma comunidade local, a pesquisa de Freitas dedicou-se a analisar as afro-descendências em diáspora, debruçando-se sobre as práticas de adeptos brasileiros que migraram para os EUA. Para o autor, os sites de matriz africana atuam não somente como um espaço de divulgação e preservação do patrimônio simbólico dessas religiões, mas também como uma forma de midiativismo que facilita encontros de adeptos no ambiente offline. Significativa também é a questão do segredo ritual: Freitas observou que nas listas de discussão presentes em alguns sites - dos quais participavam iniciados e também simpatizantes - os adeptos avançavam questões sobre interditos e segredos de culto. Entretanto, as hierarquias religiosas mantinham-se no ambiente online, com a manutenção de listas em separado para iniciados e não-iniciados quando o assunto de interesse envolvia segredos rituais (FREITAS, 2008).

Temos, assim, um espaço de diferenças matizadas nos padrões de apropriação da Internet e dos telefones celulares entre os praticantes de religiões afro-brasileiras e os evangélicos. Pesquisando sobre a Igreja Universal do Reino de Deus e o papel da Internet em 
suas narrativas de expansão global, Oosterbaan (2011) assinala o papel das ferramentas de participação na Internet que a Web 2.0 propicia. Ao se fazerem presentes nos diversos sites de redes sociais, tais como o Facebook, Twitter, YouTube, ou Orkut; ao manterem blogs e websites; e ao utilizarem não somente estas, mas também o telefone celular como instrumento de evangelização, as igrejas evangélicas - e também a Igreja Católica, como nos ensinam Horst e Miller (2000) - revelam que a cultura da participação, ou a cultura da convergência, como prefere Jenkins (2009) também deve ser associada às práticas tecno-espirituais. Se, para Jenkins (2009) a cultura da colaboração, do compartilhamento de conteúdos gerados pelos próprios usuários - que passam a ser também produtores - e a utilização de narrativas em diferentes arranjos midiáticos tende a estimular a remediação (BOLTER E GRUSIN, 1999) de conteúdos similares dentro de diferentes contextos, é preciso levar em conta que tais remediações se tornaram uma das características mais marcantes das culturas de consumo contemporâneas.

Nesse sentido, Oosterbaan argumenta que as transformações engendradas pelas tecnologias de comunicação e informação nas práticas religiosas do pentecostalismo não devem ser vistas à margem das transformações culturais contemporâneas - muito pelo contrário: devem ser consideradas como fazendo parte central da cultura da convergência contemporânea (OOSTERBAAN, 2011). Os media não funcionam, como já foi exaustivamente argumentado (HINE, 2004, MCLUHAN, 1971) como canais neutros de comunicação: assim, a Internet e outras TICs devem ser consideradas tanto artefatos culturais - produzidos por relações socioculturais - e um espaço - onde tais relações são constituídas, renegociadas e contestadas.

Assim, o que nos interessa agora descrever e analisar é a maneira pelas quais a cultura da convergência, em sua interface com as práticas de religiosidade, acontece entre os evangélicos habitantes da Vila Sandra, um bairro de camadas populares de Curitiba.

\section{AS PRÁTICAS TECNO-ESPIRITUAIS DOS EVANGÉLICOS DAS IGREJAS PENTECOSTAIS DA VILA SANDRA}

Entre as quarenta mulheres, beneficiárias do Programa Bolsa-Família, entrevistadas para a etnografia sobre a apropriação sociocultural de telefones celulares entre mulheres de camadas populares (SILVA, 2011), mais de sessenta por cento declararam-se evangélicas. 
Uma análise geral do perfil sociodemográfico dessas mulheres revela que a maioria têm baixa escolaridade: das quarenta e uma mulheres da amostra, 65,85\% (27 informantes) não chegaram a completar o Ensino Fundamental; ou seja, estudaram por sete anos ou menos. Oito informantes possuem o Ensino Fundamental completo (19,50\%); quatro possuem o Ensino Médio incompleto (9,75\%). Apenas duas informantes (4,87\%) completaram o Ensino Médio. A maior parte (78\%) está em um relacionamento estável com marido ou companheiro e, em termos de renda, em média ganham em torno de um salário-mínimo ( $\mathrm{R} \$ 622,00)$. Em média, as mães da Villa Sandra recebem R\$ 80 (em torno de USD 47) mensalmente do BolsaFamília. A maioria não possui casa própria, morando com familiares (geralmente suas próprias mães) ou em imóveis alugados de terceiros. As mulheres de nossa amostra trabalham em ocupações pouco qualificadas, tais como empregadas domésticas, auxiliares de serviços gerais, cozinheiras, ou catadoras de material reciclável. As idades das informantes variam entre vinte e cinquenta e nove anos, mas são jovens em sua maioria: 73\% têm menos de trinta e oito anos de idade, e a grande maioria teve seu primeiro filho ainda na adolescência, motivo citado por muitas para a interrupção dos estudos. A maioria das mulheres da amostra são religiosas: 61\% declararam ser evangélicas (de variadas denominações pentecostais); $27 \%$ declararam-se católicas e apenas $12 \%$ disseram que não freqüentam nenhuma denominação religiosa regularmente.

Entre as mulheres da Vila Sandra que frequentam igrejas pentecostais, o discurso religioso reveste e atravessa a tecnologia. Assim, temos que o telefone celular se torna uma “invenção de Deus”, a qual deve ser usada para Sua honra e glória. Bia, por exemplo, que se autodeclara adventista do sétimo dia, "mas anda meio afastada da Igreja”, é faxineira e, aos 47 anos, recebe 22 reais por mês do Bolsa-Família para cuidar do filho caçula, de nove anos, que precisa de atendimento psiquiátrico. Bia faz menção à narrativa religiosa para falar da importância do telefone celular para ela: “Foi uma bênção na minha vida”. Por outro lado, seu Raimundo, pai de outra entrevistada, Alice, comemorou durante a entrevista uma ligação recebida que lhe avisou de um novo emprego. Seu Raimundo, aos 66 anos, é aposentado e ganha um salário mínimo, mas faz bicos e emprega-se como porteiro em condomínios próximos da Vila Sandra, o que garante certa estabilidade financeira à família. Seu Raimundo atribui a ligação à providência divina: 
Você veja, passar mensagem eu não sei ainda... Aparece uma mensagem eu mando para as filhas ler. 'Era pra ontem', elas me disseram. Perdi o serviço, mas tem que entender que era da vontade do Senhor. De madrugada, tocou uma vez só, eu já atendo. Queriam dar um terno prá mim, mas o terno não se comunica... Agora não, pela vontade de Deus ligaram no celular e eu tou empregado.

Assim, o telefone celular passa a fazer parte de um circuito no qual a vivência da religiosidade é tida como um valor positivo, que contribui para a união familiar, a segurança e o bem-estar, especialmente dos jovens - "é bom ter uma religião”, relataram as mães. A religião mantém os jovens longe das drogas, acreditam elas (não tomam “porcarias”), da violência, da “confusão”.

Similarmente ao que discuto em minha tese de doutorado (SILVA, 2010), também observamos na Vila Sandra a prática do envio do chamado "torpedo bíblico”, que consiste no envio, através de mensagens de texto, de versículos retirados da Bíblia. Vivian, por exemplo, recebe diariamente em seu celular “torpedos bíblicos” de seu irmão, os quais mantém zelosamente armazenados. Jeanne, uma zeladora de 39 anos de idade, três filhos, membro da Igreja do Evangelho Quadrangular, relata que a prática é bastante frequente entre os membros de sua igreja. Martinha, cuja mãe, Esmeralda, é diaconisa nessa mesma denominação religiosa, relata que ainda não viu pessoas passando mensagens de conteúdo religioso, mas conhece a prática. Ao mesmo tempo, em seu relato esclarece que a Quadrangular já se utiliza de sites de redes sociais para marcar presença na Internet:

Diretamente eu não vi, mas o pastor disse que eles tem um trabalho por esse negócio do computador, MSN e Orkut, e pelo SMS também, e esse negócio novo, tui, twitter. Parece que as pessoas que não tem Internet recebem os versículos bíblicos pelo celular. Aí eles pegam o nome da pessoa, que ligou pedindo ajuda, e mandam as mensagens. Às vezes porque as pessoas não tem telefone, nem computador, e mandam pelo celular. Às vezes não é nem membro da igreja. Eu não vi. Mas tem a pessoa dentro da igreja, na sala, que às vezes tá com dois ou três celulares.

Diferentemente da Quadrangular, uma igreja pentecostal com uma boa estrutura de comunicação - a própria Igreja do Evangelho Quadrangular da Vila Sandra tem sua própria página no Facebook, além de estar presente no Twitter e com um canal de vídeos no You Tube - a Igreja Pentecostal Casa Favorita existe apenas na Vila Sandra. Foi fundada pelo pastor Roberto e sua esposa, Aparecida. Como Edineia, que carrega três celulares para ficar 
sempre disponível a seus fiéis (SILVA, 2009) a pastora Cida carrega um celular com dois chips (cartões pré-pagos de diferente operadoras). Assim como Vivian, Jeanne e Martinha, o pastor Roberto também pratica o envio de mensagens espirituais por torpedo de celular:

Eu acho isso muito interessante, muito bom. De repente ela nem está esperando, e vê lá: uma mensagem. "O senhor é meu pastor, nada me faltará”. Eu não mandei mensagem para evangelizar, mas para conforto espiritual. Um versículo. A pessoa disse que é justamente o que ela estava precisando.

A Casa Favorita também tem site próprio - embora ainda em fase de construção - no qual se compartilham fotos dos cultos, vídeos dos batismos e, mais importante, também há a página de testemunhos e a dos pedidos de oração. A respeito do papel da Internet na vida dos fiéis, o pastor Roberto esclarece que "agora que a gente criou um site, as pessoas ligam pedindo oração e também pelo site. No celular eu recebo de quatro a seis ligações por dia. Também tenho o telefone fixo, mas só fico em casa à noite”. Interessante notar, entretanto, que a maior parte das ligações e dos pedidos de oração recebidos não são de pessoas da própria congregação, mas sim de estranhos: “Gente de Foz do Iguaçu, Belo Horizonte, Ponta Grossa, gente que eu nunca vi na vida. A maioria, por incrível que pareça, é gente que eu não conheço”. A seguir, o pastor Roberto arrisca uma explicação para essa prática: “As pessoas descobriram que é mais fácil pelo tele-oração. Elas precisam da palavra de Deus - a boca fala daquilo que o coração está cheio”. Penso que neste ponto é possível estabelecer um paralelo entre a prática da “tele-oração” evangélica, bem como o pedido de oração pela Internet, com a prática da confissão religiosa on-line da Igreja Católica, estudada por Miller e Slater (2000), em Trinidad. Para os autores, existe uma tensão normativa entre a tradição católica da absolvição presencial e o anonimato proporcionado pela Internet. Miller e Slater observaram que, se para alguns sacerdotes católicos a confissão on-line era um exemplo de comunicação mediada por computador que podia cumprir com o rito sacerdotal de forma análoga às práticas tradicionais - na medida em que a Internet propicia um anonimato similar ao da tela do confessionário, que separa sacerdote e penitente - para outros, na ausência física do sacerdote, não era possível fornecer a absolvição. Tensão semelhante entre o "tradicional” e o “moderno” foi observada por Katz (2006): nas Filipinas, a confissão on-line foi aceita por um período pela Igreja Católica, para ser declarada sem valor posteriormente. Na Vila Sandra, duas informantes católicas, Ana e Méri, que são semi-analfabetas, foram ensinadas pelos 
filhos a entrar em sites católicos. Ambas escutam pelo rádio os programas dos padres-cantores Marcelo Rossi e Reginaldo Manzotti, e depois procuram mensagens na Internet: "Dá prá entrar no site dele, pedir oração. Já procuramos e já encontramos e é verdade. Sempre eles mandam jornalzinho. Aí a gente viu”.

Se na Igreja Católica a confissão on-line se tornou um "gênero cultural” (MILLER E SLATER, 2000) contestado, o que observamos na Vila Sandra foi um amplo uso do telefone celular como forma de prover conforto espiritual. Várias das informantes relataram que os pastores de suas igrejas divulgam os números dos celulares pessoais e se colocam à disposição para prestar apoio emocional. Martinha, por exemplo, fala a respeito de sua mãe, diaconisa da Igreja do Evangelho Quadrangular:

\begin{abstract}
Diaconisas usam celular para evangelizar. A mãe é que ia saber mais. Mas tem bastante que sai prá fora, pra visitar hospitais, cadeia. Uma vez elas vieram aqui orar pela minha mãe. Duas pegaram o celular, desligaram e colocaram na estante prá começar a oração. Teve uma que colocou prá gravar, acho que era só as vozes, os testemunhos, mas eu não fiquei sabendo certinho. A gente orando, cantando, ela ficava com o celular o tempo todo, de vez em quando dava uma olhada. Mas ela tava gravando.
\end{abstract}

Essa produção de narrativas religiosas, seja no formato da gravação em áudio e vídeo dos testemunhos ou por outras formas, frequentemente é remediada para os sites da Internet das igrejas pentecostais da Vila Sandra. O gênero cultural do testemunho está presente em todos eles - seja no site da Assembleia de Deus, da Igreja do Evangelho Quadrangular ou mesmo da Casa Favorita. Vale ressaltar também que todos possuem vídeos no site de compartilhamento YouTube. Em todos os sites analisados, como o da Assembleia de Deus da Vila Sandra, o internauta pode encontrar testemunhos, pedidos de oração e estudos bíblicos.

Concordamos com Miller e Slater (2000) que, ao analisarem os discursos religiosos em Trinidad, observaram que a Internet e os telefones celulares são tidos como parte de um projeto divino para espalhar a palavra de Deus (spread the word) em nível global. Para o pastor Roberto, os telefones celulares e o site da Casa Favorita, nesse sentido, garantem o “contato perpétuo” (KATZ, 2006) assegurando a disponibilidade: "Engraçado que eu penso assim. Nosso trabalho é abençoar a família com o poder da palavra de Deus. E a gente tem que estar disponível a qualquer hora e a qualquer momento”. Segundo ele, setenta por cento das ligações que recebe são de mulheres que são mães - “a mulher é mais sensível a abrir o 
coração para pedir ajuda” - que pedem principalmente pelos filhos, temendo o envolvimento com drogas, e pedem também que os maridos não caiam na tentação de as traírem.

De maneira similar, Oosterbaan (2011) traça uma relação entre a cultura da convergência (JENKINS, 2008) e as práticas de religiosidade da Igreja Universal do Reino de Deus:

A descrição da igreja de seu próprio portal [na Internet] é a do "evangelho sem barreiras”, o que nos traz os discursos cristãos a respeito da Internet. Enquanto certamente há muitos grupos cristãos que se debatem com alguns dos aspectos e conteúdos da Web, em geral os cristãos interpretam os avanços nas tecnologias de comunicação - incluindo a Internet - à luz do cumprimento das profecias milenaristas sobre a segunda vinda de Jesus Cristo após cada ser humano na face da Terra ter ouvido o Evangelho (OOSTERBAAN, 2011, p. 61).

O depoimento de Lia, uma jovem mãe da Igreja Congregação Cristã do Brasil, também ressalta as tensões existentes na apropriação da tecnologia nas práticas tecnoespirituais. Lia ressalta o conteúdo apropriado para um “celular evangélico”, revelando que possui muitos torpedos bíblicos guardados na memória do aparelho. Seu marido, assim como Lia, em uma expressão de identidade religiosa, tem como papel de parede do celular a imagem do templo maior da Congregação Cristã do Brasil, localizado no bairro Portão, em Curitiba. A respeito de tais tensões, o pastor Roberto marca a posição da Casa Favorita:

Você não vai se apartar do mundo. Tem igrejas que proíbem. A gente sairia fora do mundo. A pessoa ficaria atrasada. Tudo é Internet, tudo é celular. Então, a gente diz: "vigiai!” Cuidado com o conteúdo, o que guarda, principalmente a música. Porque a música não toca só a alma, toca o corpo [...] Existem espíritos mundanos que entram na mente das pessoas, cauterizam a mente. De repente o jovem que não fumava, não bebia, pode passar a ter vontade por causa de uma música que tem no celular. Parece patético falar isso, mas é verdade.

Entretanto, não são apenas os pastores que prestam apoio emocional por telefone. Há redes de mulheres que prestam apoio entre si, especialmente nas relações de amizade e parentesco. Genoveva, por exemplo, é uma senhora de 58 anos, inscrita no programa Bolsa Família, que cria os netos sozinha. Uma de suas filhas, que mora em outra cidade, estava em certa ocasião com o bebê doente. Ligou para a mãe pedindo orações e, nesse momento, Genoveva conta que foi “inspirada por Deus” e começou o orar pelo celular. Outra amiga, que 
tinha problemas de saúde, também liga cotidianamente pedindo orações. Genoveva diz que está sempre disponível para prestar esse apoio espiritual, e apenas lamenta não saber mandar mensagens de texto. Diz ela: “porque eu acho legal essas mensagens bíblicas no celular. Quero aprender a fazer, assim posso mandar para o meu irmão, que mora longe. Queria mandar uma mensagem dizendo 'Deus te ama'”, revela.

\section{CONDIDERAÇÕES FINAIS}

Vimos ao longo deste artigo como a apropriação de tecnologias de comunicação e informação - notadamente a Internet e os telefones celulares - reveste as narrativas das igrejas pentecostais de significados religiosos, os quais dão conta da crença em um "projeto divino” para a tecnologia, qual seja, o de levar a palavra de Deus a todos, em nível global. Ao mesmo tempo, com a Web 2.0, as ferramentas de participação e compartilhamento - de imagens, de arquivos em áudio e também em vídeo - é grandemente potencializada. Assim, as práticas tecno-espirituais, ao se tornarem parte cada vez mais presente na vivência de religiosidade - muito embora sempre tenham feito parte da vida social - apontam para o florescimento de uma cultura da convergência (JENKINS, 2008) que pode ser verificada em nível global, compondo um mediascape (APPADURAI, 1998) que inclui as práticas dos evangélicos da Vila Sandra.

\section{REFERÊNCIAS}

AGAR, Jon. Constant Touch: a global history of the mobile phone. Cambridge: Icon Books, 2003.

APPADURAI, Arjun. Modernity at Large: cultural dimensions of globalization. Minesota University Press, 1998.

BARENDREGT, Bart; PERTIERRA, Raul. Supernatural mobile communication in the Phillipines and Indonesia. In: KATZ, James E. Handbook of Mobile Communication Studies. Cambridge: MIT Press, 2008, 377-388. 
BARRANTES; Roxana; GALPERÍN, Hernan. Can the poor afford mobile telephony? Evidence from Latin America. Lima: DIRSI, 2008. Disponível em: < http://dirsi.net > Acesso em: 26 mai. 2011.

BELL, Genevieve. No more SMS from Jesus: ubicomp, religion and techno-spiritual practices. In: DOURISH, P.; FRIDAY, A. (orgs.). UbiComp 2006: Ubiquitous Computing, Vol. 4206 (2006), pp. 141-158. doi:10.1007/11853565_9, 2006. Disponível em: < http://www.citeulike.org/user/ingstrup/article/5491459 > Acesso em: 20 mai. 2011.

BOLTER, Jay; GRUSIN, Richard. Remediation. Understanding New Media. Cambridge: MIT Press, 1999.

CAMPBELL, Heidi. Texting the faith: religious users and cell phone culture. In: KAVOORI, Anandam; ARCENEAUX, Noah (orgs.). The cell phone reader: essays in social transformation. New York: Peter Lang Publishing, 2006, p. 139-154.

CASTELLS, Manuel. Afterword. In: KATZ, James E. Handbook of Mobile Communication Studies. Cambridge: MIT Press, 2008, p. 447-451.

CASTELLS, Manuel; FERNÁNDEZ-ARDÈVOL, Mireia; QIU, Jack Linchuan; SEY, Araba. Mobile Communication and Society: a global perspective. Cambridge: MIT Press, 2007.

FORTUNATI; Leopoldina; VINCENT, Jane. Introduction. In: FORTUNATI; Leopoldina; VINCENT, Jane. Electronic Emotion: the mediation of emotion via information and communication technologies. Oxford: Peter Lang, 2009.

FREITAS, Ricardo. Religiões afro-derivadas em rede: mídia alternativa para minorias étnicoraciais, religiosas e nacionais nos EUA. In: TRIVINHO, Eugênio; KISHIMOTO, André Franzosi; LIMA, Paulo Alves de. Anais do Simpósio Nacional da ABCiber - Associação Brasileira de Pesquisadores em Cibercultura. São Paulo: CENCIB/PUC-SP, CAPES, 2008. Disponível em: <http://www.cencib.org/simposioabciber> Acesso em: 14 mar. 2011.

JENKINS, Henry. Cultura da Convergência. 2a . Ed. São Paulo: Aleph, 2009.

HINE, Christine. Etnografía Virtual. Barcelona: Editorial UOC, 2004.

HORST, Heather; MILLER, Daniel. The Cell Phone: an Anthropology of Communication. Oxford; Berg, 2006.

KATZ, James. Magic in the air: spiritual and transcendental aspects of mobiles. In: KATZ, James. Magic in the air: mobile communication and the transformation of social life. New Brunswick, NJ: Transaction Publishers, 2006. Disponível em: < http://www.socialscience.tmobile.hu/2005/Katz.pdf > Acesso em: 20 mai. 2011.

MARIANO, Ricardo. Neopentecostais: sociologia do novo pentecostalismo no Brasil. São Paulo: Loyola, 1999. 
MARIZ, Cecília Loreto. Coping with poverty: pentecostals and christian base communities in Brazil. Philadelphia: Temple University Press, 1994.

MCLUHAN, Marshall. Os meios de comunicação como extensões do homem. São Paulo: Cultrix, 1971.

MILLER, Daniel; SLATER; Don. The Internet: an ethnographic approach. Oxford: Berg, 2000.

OOSTERBAAN, Martijn. Virtually global: online evangelical cartography. Social Anthropology/Anthropologie Sociale, número 19, p. 56-73, 2011. Disponível em: < http://onlinelibrary.wiley.com/doi/10.1111/j.1469-8676.2010.00138.x/abstract > Acesso em: 20 mai. 2011.

PRANDI, Reginaldo. Segredos guardados: orixás na alma brasileira. São Paulo: Companhia das Letras, 1995.

SILVA, Sandra Rubia. A religião dos celulares: consumo de tecnologia como expressão de fé entre evangélicos e umbandistas. Anais do XXXII Congresso Brasileiro de Ciências da Comunicação, Curitiba, set. 2009.

SILVA, Sandra Rubia.. Estar no tempo, estar no mundo: a vida social dos telefones celulares em um grupo popular. Tese (Doutorado em Antropologia Social) - Universidade Federal de Santa Catarina, Florianópolis, 2010.

SILVA, Sandra Rubia. Telefonia móvel e questões de gênero aspectos socioculturais da apropriação de telefones celulares entre mulheres em situação de vulnerabilidade social. Lima: Diálogo Regional Sobre Sociedad de la Información, 2011. Disponível em: < http://dirsi.net/sites/default/files/RUBIA\%202011\%20-

\%20Telefonia\%20M\%C3\%B3vel\%20e\%20questoes\%20de\%20genero_0.pdf > Acesso em: 20 mai. 2011.

TELECO. Estatísticas de Celulares no Brasil. Teleco: Informações em Telecomunicações, 2012. Disponível em: < http://www.teleco.com.br/ncel.asp > Acesso em: 20 mai. 2012.

TRAMONTE, Cristiana. Com a Bandeira de Oxalá: trajetórias, práticas e concepções das religiões afro-brasileiras na Grande Florianópolis. Itajaí: UNIVALI, 2001.

Os sítios e os sites do candomblé na Internet: a convivência entre modernidade e tradição. Vozes \& Diálogo, Revista do Laboratório de Mídia e Conhecimento do CEHCOM/UNIVALI. Vale do Itajaí, ano 3, nr. 3, abr. 1999, p. 50 - 55. Itajaí: Laboratório de Mídia e Conhecimento, 1999. 96p.

Original recebido em: 05/01/2012

Aceito para publicação: 10/07/2012

ANIMUS R. Interamericana de Comunicação Midiática, http://www.ufsm.br/revistas E-ISSN 2175-4977, v. 11, n. 21, Jan-Jun(2012) 
Doutora em Antropologia Social pela Universidade Federal de Santa Catarina - UFSC, com estágio de doutoramentosanduíche no Departamento de Antropologia do University College London, Reino Unido. Mestre em Comunicação e Informação pela Universidade Federal do Rio Grande do Sul UFRGS. Docente do Departamento de Ciências da Comunicação da Universidade Federal de Santa Maria UFSM.

E-mail: sandraxrubia@gmail.com 